\title{
The Young Adults Form of the Attitude toward Women's Working Scale: Development, Preliminary Validation and Measurement Invariance
}

\author{
Devrim Erdem (iD) 1 * \\ ${ }^{1}$ Department of Educational Sciences, Nigde Omer Halisdemir University, Turkey
}

\begin{abstract}
ARTICLE HISTORY
Received: 08 May 2019

Revised: 24 December 2019

Accepted: 06 January 2020

KEYWORDS

Attitude,

Women's working,

Scale development,

Configural invariance,

Metric invariance

Abstract: The purpose of this study was to develop a scale measuring attitudes toward women's working. In line with this main purpose, two studies were conducted to develop the tool and investigate its psychometric properties in two different samples. The study 1 started with generating item pool, conducting exploratory factor analysis to identify underlying factor structure of the latent variable. In study 1 after testing the structure of measure, a brief 9-item, tri-factor scale for the assessment of attitudes toward women's working was emerged. The study 2 utilized a different sample. In study 2, it was aimed to examine model fit, test measurement invariance acroos gender and investigate reliability. Validity and reliability of the scale indicated that the attitude toward women's working scale (ATWWS) had satisfactory psychometric properties. In study 2 , configural and metric invariances of the ATWWS were supported for females and males.
\end{abstract}

\section{INTRODUCTION}

One of the important criteria for a society's advancement is that individuals can participate in a fair labor market and have equal opportunity for acquisition of welfare. Given that women are nearly half of any given human society, examination of a society's human capital and the efficiency which it is being used cannot be done without taking women into account. Women's participation into public life as well as into work place is of paramount importance in today's societies. On the other hand, the existing gender inequalities pose extra challenges for those women who do participate in the labor market (Forsythe, Korzeniewicz, \& Durrant, 2000; Himmelweit, 2002).

One could easily claim that women have always partaken in production throughout all human history. However, when compared to men, women's attendance in the public life and in paying jobs has not been to a satisfactory degree all along (Kakıcı, Emeç, \& Üçdoğruk, 2007). In the case of Turkey, while women's employment in both industrial and service sectors was $3.86 \%$ in 1955, it was 40.9\% in 2000 (Turkish Statistical Institute, [TUIK], 1990, 2000). Women's employment rate in the total labor market was $23.3 \%$ in 2004, it reached 30.8\% in 2013 (Turkish Ministry of Labor, Social Services and Family, [MLSSF], 2014). Looking at women's (age 15 and up) employment according to their educational level shows intriguing results: Their

CONTACT: Devrim Erdem $₫$ erdem_devrim@yahoo.com

Omer Halisdemir University, Turkey

Department of Educational Sciences, Nigde 
employment rates increase with their levels of education. Women with illiteracy had a rate of $16 \%$ while the rate of those with university degrees was $71.3 \%$ (TUIK, 2016). These statistics show that women's participation in the work place has been increasing but it is still far from being equal to those of men. Indeed, employment rate among men is $65.1 \%$ while women's rate is $28 \%$ (TUIK, 2016). In other words, women's employment is not even at the half level of that of men. A closer look at the nature of males' and females' employment shows even more striking discrepancies. Women work in part time job three times more than men $(6.5 \%$ men; $19.1 \%$ women). Women's employment in mid or high-level administrative positions is only 16.7\% (TUIK, 2016). In other words, males occupy incomparably more decision-making positions than females.

When women's employment rates in Turkey are compared to those of women in Europe or in the OECD countries, the results are not quite promising. These rates are over $60 \%$ in Europe and in member countries of the OECD while they are under 30\% in Turkey (OECD, 2016). In its 2018 report on the Global Gender Gap Report (GGGR, 2018), the World Economic Forum indicated that Turkey ranked $130^{\text {th }}$ among 149 countries with respect to women's employment. The same report illustrates that Turkey ranked $131^{\text {st }}$ in terms of women's participation in the economy and of equal opportunities. Further, it ranked $106^{\text {th }}$ in terms of women's education and $113^{\text {rd }}$ regarding women's political participation. The same report shows that a significant increase occurred in women's employment rate, during the current decade while their earning was $51 \%$ of that of men. Statistics show a global decrease in women's employment and attribute this decrease to increased utilization of technology. The report finally indicates that women's participation in areas of science, technology and mathematics is still far from being equal to that of men.

Considering cultural values and norms in Turkey, these statistics are not surprising. A host of aspects of the culture in Turkey reflect a highly sexist and gendered view (Kuzgun \& Sevim, 2004). Thus, from how parents raise female and male children, to how motherhood is idealized to a lack of legal protection of women, there are numerous aspects of the culture, its legal system, family functioning that limit women's roles merely within a traditional patriarchal domain. Gender refers to meanings and expectations a society or culture attributes to its males and female members (Lips, 2001). In the Turkish culture, while females are expected to be patient, sensitive, caring, passive and dependent, males are expected to be assertive, dominant, strong, independent, competitive and determined (Dökmen, 2004; Heilman, 2001; Özkaplan, 2013). Both families and the general society provide messages defining gender roles by both overt and covert means (Ersoy, 2009; Tan, 2000).

Women embracing the roles of wives and mothers (Özcatal, 2011), women who have economic resources preferring not to work (Koray, 1992), women's work depending upon the permission of husbands (Özcatal, 2011) are all indicative of the fact that the culture still heavily promotes traditional-patriarchal gender roles. The home and household works seem to be essential in defining women's identity (Bora, 2011). In other words, the cultural gender stereotypes attributing roles of wives and mothers as women's primary duties seem to still highly prevalent (Aktaş, 2013, Bingöl, 2014; Nergiz \& Yemen, 2011). Such traditional roles and expectations are likely to impede with women's likelihood to partake in the work force and limiting their aspirations (Aktaş, 2013; Dökmen, 2004).

Gender roles have significant impact on individuals' careers as well as institutions of any given society. A male-oriented workforce and organizational culture also constitutes challenges for women and impact their career choices (Britton, 2000; Özar, 2005). Indeed, teaching seems to be number one preferred occupation that women choose both for themselves and for their daughters (Özcatal, 2011). Likewise, they prefer occupational areas such as nursing or counseling that extend their caring roles as wives and mothers to their careers. 
The relevant literature on women's participation into the workforce shows that there are numerous factors such as motherhood and familial responsibilities, caring for the elderly (Dayığlu \& Kırdar, 2010; Palaz, 2015; Yamak, Abdioğlu \& Mert, 2012) age, marital status, educational level, place of residence, number of children, spouse's level of education seem to significantly impact their involvement in paying jobs (Akın, 2002; Bölüköğlu, 2018; Gürler \& Üçdoruk, 2007; Kılıç \& Öztürk, 2014; Kıral \& Karlılar, 2017; Şengül \& Kıral, 2006; Yıldırım $\&$ Doğrul, 2008). Moreover, high unemployment rates of women are major discouraging factors affecting women's participation in the labor market (Tansel 2002; Kizılırmak, 2005). Thus, many developed and developing countries have implemented state policies encouraging women's employment (Kakıc1, Emeç \& Üçdoğruk, 2007). Turkey too, in its highest document for state policies, $10^{\text {th }}$ Development Program (2014-2018) specified concrete measures to take to improve women's participation in workforce. Indeed, part of the development program has been the Priority Transformation Program that identifies obstacles to women's employment and specific measures by which they can be reduced (MLSSF, 2014). Gender equality and empowerment of women are essential among the most important priorities declared by the United Nations Millennium Development Goals (United Nations, [UN], 2012). This requires significant improvements in women's rates of participation in the workforce.

Even in the development plans of those countries that have relatively advanced in development, there are interventions geared toward improvements in women's employment. Thus, the need for advancement in women's participation in the work force is far from being specific to Turkey and is rather a global issue. Traditionally, modern society allocated different social roles to men and women in the division of working life (Alwin, Braun \& Scott, 1992). Women, in particular those with young children, work part-time, and they still provide free care (Scott \& Clery, 2013). The fact that women have more responsibility in childcare leads to a decrease in women's working hours, while it on the contrary leads to increase in men's working hours (Kaufman \& Uhlenberg, 2000). Time spent on domestic labor adversely affects women's earnings and career performance (Hersch \& Stratton, 2002). Regardless of national boundaries men are not high likely to approve of women working when there are preschool or young children at home, and clearly, it is considered more reasonable for women to take care of children (Alwin, Braun, \& Scott, 1992). Despite progress made around the world, women are still concentrated in gender-segregated jobs such as teaching, nursing, clerical, sales and service occupations (Ferraro, 2010). In Canada women still occupy the majority of part-time lowincome jobs; of all part-time workers in 2009 , nearly seventy percent were women and they were taking upon the added burden of childcare (Ferraro, 2010). In the UK, even if women are beginning to represent a growing proportion of the working population, this does not indicate that they are beginning to breakdown gender segregation within certain professions (i.e., women are overrepresented in office and secretarial positions) (Agapiou, 2002). Again, in the UK, $41 \%$ of women in employment were working part-time compared to $13 \%$ of men; and because the per hour earning of part-time workers is less than full-timer workers, the gender pay gap was greater for all employees (Powell, 2019). In the US, although women participation in labor pool has increased, women still undertake $65 \%$ to $80 \%$ of chores in home (Bianchi, Milkie, Sayer, \& Robinson, 2000; Coltrane, 2000). Furthermore, 43.2\% of women in employment were working in gender-segregated jobs such as health care, non-governmental education, leisure, janitor, secretary, accountant and other services (U.S. Bureau of Labor Statistics, 2019).

Despite changes in policies, improved legislation and efforts toward improving women's participation in the labor market, patriarchal values seem to significantly influence women's decision making in choosing the kinds of workplaces, occupations and jobs (Köseoğlu, 2017). Likewise, discrimination and inequality pose extra challenges in women's education as well as work lives. Norms, perceptions and prejudice on gender stem from past history, economic and 
societal circumstances, political regimes, religion and cultural values (Kırkpınar, 2001). In this way, individuals are exposed to these norms and values from the onset of their lives. Corrigall and Konrad (2007) pointed out that early gender role attitudes of women effect women's later career and earnings. Since both married women and men support traditional gender roles (Gubernskaya, 2010), the thoughts and behavior patterns of children regarding gender roles have been shaped from an early age. As a result, individuals' schemas, perceptions and attitudes regarding males' and females' work are shaped starting from early developmental stages and become firmer and more resistant to change as individuals proceed in their life span development.

An attitude is considered as an individual's general and enduring evaluation of an object or concepts. These evaluations can be about almost anything, including persons, social groups, physical objects, behaviors, and abstract concepts (Fabrigar, MacDonald, \& Wegener, 2005). Allpot (1935) described attitude as "a mental and neural state of readiness, organized through experience" (p.810). According to Allport (1935), attitudes exert a directive or dynamic effect on an individual's reaction to all the objects and situations to which it relates. In this definition the expression of "a mental and neural state of readiness" particularly highlights the basis of attitudes. A remarkable number of models have been developed to identify attitude formation and change, but most of these models focus on cognitive processes (Maio, Haddock, \& Verplanken, 2018). The cognitive component of attitudes indicates beliefs and thoughts related to an object. Indeed, the amount of knowledge on which the attitude is based affects the function of the attitude. The content and the breath of knowledge toward the object are the associative links making up the attitude (Fabrigar \& Wegener, 2010). Attitudes can influence individuals' learning (Brewe, Kramer, \& O'Brien, 2009; Perkins, Adams, Pollock, Finkelstein, \& Wieman, 2005), perception (Ajzen, 1989; Hinner, 2019), reasoning and thinking (Yinger, 1980). Attitudes also influence individuals' interpretation of information and memory processes (Blackton, 1986; Fabrigar \& Wegener, 2010). Thus, in the current study, while forming the items of the scale a great deal of emphasis was placed on the cognitive aspect of attitudes toward women's working.

There have been a number of studies with Turkish samples exploring attitudes toward women's work. Most of these studies (Çiçek \& Çopur, 2018; Koca, Arslan, \& Aşçı, 2011) have used the scale developed by Kuzgun and Sevim (2004). The scale was developed with a sample of 112 adults (Kuzgun \& Sevim, 2004). The authors began their scale development study with a form consisting of 27 items. Then, their exploratory factor analysis resulted in a scale made of five factors. Then, the authors eliminated 12 items. The remaining 15 item - form gathered in one factor with an internal consistency coefficient of .92. Another widely used scale was developed by Köseoğlu (2017) who attempted to measure male university students' attitudes toward women's work. Her initial scale made of 30 items was given to a sample of 251 male students. Exploratory factor analysis yielded in a four-factor structure. After eliminating 9 items from the scale, with the remaining 21 items, Köseoğlu (2017) obtained a single-factor. The last form explained $57.88 \%$ of the total variance and had an internal consistency coefficient of .93. There were some limitations of these two scale development studies. One, they worked with relatively small samples. Two, in their initial forms, exploratory factor analysis with both scales resulted in multi-factorial structures, but then the scales were transformed into a single-factor structure by eliminating items from the scale.

However, if an attitude toward women's working is a multidimensional construct, there will be some drawbacks to merging its dimensions in a single component. In such a case, the conceptualization of the construct will be insufficient. Besides, there will be a deficient understanding of the construct's antecedents and consequences (Fredricks, Blumenfeld, \& Paris, 2004). In addition, if the measures of attitudes operate differently between the comparison 
groups, the item or/and groups of items that cause this difference must be identified. If existing differences are not taken into account in the measurement process, comparisons of levels of attitudes or its effects across groups are invalid. Therefore, it is essential to provide evidence that the given construct works similarly between groups before the scores obtained from the relevant construct are used for comparison purposes. Furthermore, exploratory factor analysis (EFA) is generally recognized as initial phases of scale development. However, further statistical techniques should be applied to confirm or disprove the results obtained in the exploratory phase (Rentz, Shepherd, Tashchian, Dabholkar, \& Ladd, 2002). Due to the methodological and conceptual limitations of the existing scales, it was deemed appropriate to develop a new instrument. Thus, the scale is intended to contribute to the related literature.

Meta-analyses have indicated that there is a significant and positive correlation among the different dimensions of attitudes and these attitudes predict behavior (Glasman \& Albarracín, 2006). Baron and Bryne (2000) also stated that attitudes are an important factor that should be investigated because attitudes have a strong effect on thought and have an important effect on individual behaviors (as cited in Noor \& Saad, 2016). Individuals receive messages on gender stereotypes and attitudes at early ages from various sources such as peers, the media, family and school in both overt and covert ways. Such differential approach leads to sex differences in activities persons partake, in areas they pursue to explore their abilities and even in their career aspirations. Therefore, identifying individuals' attitudes toward women at as early ages as possible will make it more likely for interventions geared toward changing negative attitudes. Such change will not only impact the existing generations but will perhaps be passed on future generations. Thus, the current study aimed at developing a scale for assessing young adults cognitive attitudes toward women's work. In line with this main purpose, two studies were conducted to develop a tool and investigate its psychometric properties on separate samples. The study 1 started with generates item pool and then proceeded with EFA to reveal underlying factor structure of the latent variable. The study 2 utilized a different sample and involved use of confirmatory factor analysis (CFA) and intended to test measurement invariance according to gender. Initial reliability was also investigated.

\section{Study 1: Scale Development, Exploratory Factor Analysis}

\section{METHOD}

In the current study was aimed to develop an item pool and to search out the underlying structure of the items.

\subsection{Participants}

A cross-sectional sample of 364 students from a state university located in central Anatolia in Turkey was involved for Study 1. This was a convenience sample consisting of $201(55.2 \%)$ females and $163(44.8 \%)$ males. Participants' ages ranged from 19 to 24 ( $M_{\text {age }}=21.43$, $S D=1.03)$. Twenty-five percent of the respondents stated that they studied in the faculty of education, $22 \%$ in faculty of sciences and literature, $19.5 \%$ in faculty of economics and administrative sciences, $16.5 \%$ in faculty of engineering, $8.8 \%$ in school of physical education and sports and $8.2 \%$ in school of health. Fifty-eight percent of the respondents' mothers and $45 \%$ of the respondents' fathers had only primary school education. Thirty-four percent of the participants stated that they come from the Central Anatolia region and $44 \%$ of the Mediterranean region of Turkey.

\subsection{Instrument: Scale development - Item pool generation and expert review}

At the outset of the current study an in-depth review of literature was performed to specify the conceptual boundaries and dimensions of the construct. Then, an initial pool of items was generated based on a literature review of existing measures assessing attitudes toward women's 
working. At the same time 13 university students were asked to write an essay in which they expressed their thoughts about the women's work. Based on the literature and these essays, the author wrote 32 draft items. Instead of carefully selecting, if all the items are included in the form for the pilot study this will lead to response contamination (Erkuş, 2012). This recommendation by Erkuş (2012) was kept in mind; in other words, special care was given in selecting items most likely to capture the trait. Therefore, at the stage of item writing process, redundancy of items was not tolerated. In order to ensure the face-validity and the contentvalidity, two independent sociologists reviewed these items of the draft scale. Then, face-toface interviews were conducted with four individuals inquiring their opinions about the items. Ambiguous items, items with similar meaning and irrelevant items were eliminated. After the assessment, eight items were removed and the number of items in the scale was reduced to 24 according to experts' opinions. Subsequently, a Turkish language specialist reviewed the remaining 24 items and according to her feedback changes were made in some items. Participants' level of agreement on each item was determined with a five-point Likert-type. The responses vary from strongly disagree (1) to strongly agree (5).

\subsection{Procedure}

In the present study, all respondents were informed about the aim of the study and were told they were free to leave the study at any time. Then, the scale was distributed to volunteers. Application was group administered during one class session. They received no payment or extra credit for their participation. Application took approximately $20 \mathrm{~min}$.

\subsection{Data Analysis}

In order to explore the dimensions and purify the item pool of the ATWWS, exploratory factor analysis (EFA) using the principal axis factoring (PAC) extraction was performed with SPSS 22. If needed in proceeding stages an oblique rotation would be preferred. An oblique rotation allows factor to correlate (Worthington \& Whittaker, 2006) and factor inter-correlations are the norm in social sciences (Costello \& Osborne, 2005).

\section{FINDINGS}

\subsection{Data Screening}

Prior to conducting the analysis, data were subjected to monitor for missing values and outliers. Six missing values were detected. The cases having missing values were removed from the data set. Outliers were not detected in the data.

\subsection{Scale Refinement}

Exploratory factor analysis (EFA) was performed on attitude toward women's working scale (ATWWS) items. The Kaiser-Meyer-Olkin (KMO) analysis was carried out to examine sample size criteria. Since KMO index was .87 the sample size was found to be adequate. Factorability of the scores was assessed based on the Barlett's test of sphericity test that was significant $\left(\chi^{2}(36)\right.$ $=1443 ; p=0.00)$. Based on these findings it was concluded that factor analysis could be performed.

The underlying structure of the 24-item ATWWS scale was evaluated using the principal axis factoring (PAC) without rotation at first. When the eigenvalues were examined, there were six factors greater than 1. These initial eigenvalues were 7.1, 3.4, 2.3, 1.4, 1.2 and 1.1 respectively. The variances explained by these six factors were as follows: $29.6 \%, 14.4 \%, 9.6 \%, 5.9 \%, 5.2 \%$ and $4.8 \%$. On the other hand, as shown in Figure 1 the scree plot test proposed a three-factor solution. According to the scree plot it was clear that the slope after point third changes to a more straight line. In progress, many analyzes including three, four, five and six factor solutions were performed. It is desirable to maintain sufficient factor for adequate fit, "but not so many 
that parsimony is lost" (Tabachnick \& Fidell, 2001, p.620). Therefore, when deciding factor retention, item loadings, eigenvalue, scree plot test, explained variances but especially the interpretability of the items under the factors were taken into consideration. Taken together, in this case the number of optimal factors was considered to be three. Once it was decided to number of factor, the EFA with oblique rotation for three-factor restriction was performed. After conducting EFA distinct three factors were emerged.

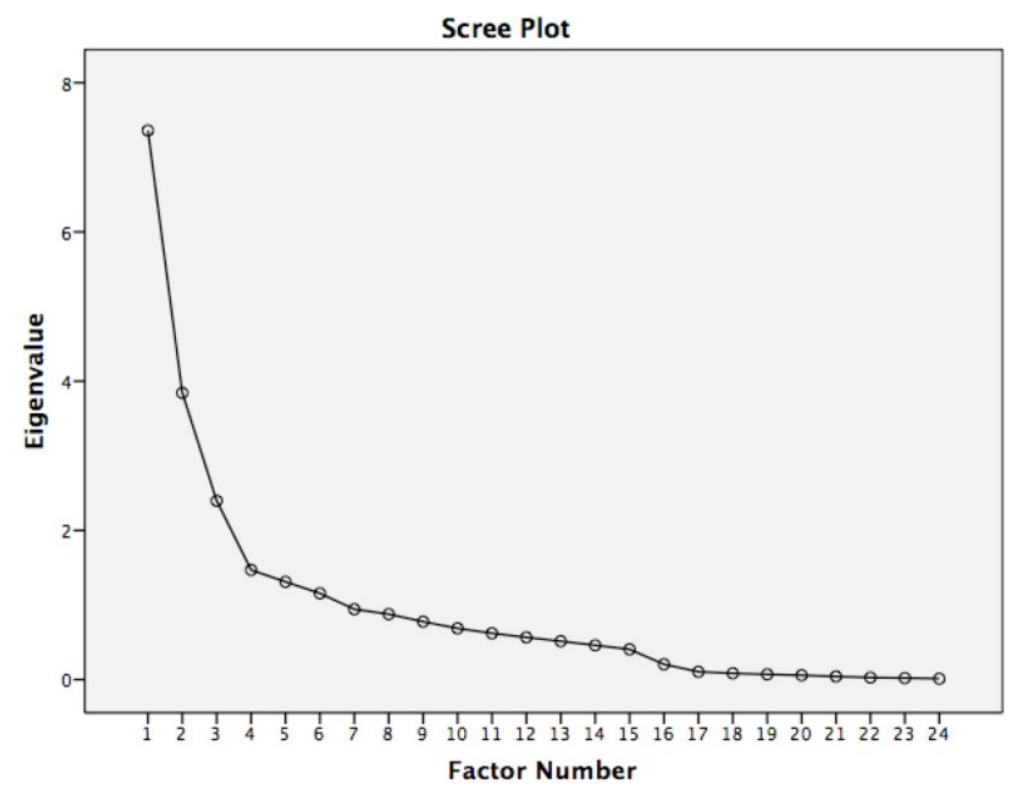

Figure 1. Scree Plot

In order to purify the scale, items with low communalities (less than .40), low factor loadings (less than .40) and/or cross-loadings (less than .20) were eliminated. This resulted in removing 15 items from the scale. Thus, nine items remained on the scale. The factor loadings and communalities of the scale were presented in Table 1.

Table 1. Principle axis factoring with oblique rotation Pattern matrix for the final ATWWS items

\begin{tabular}{|c|c|c|c|c|c|}
\hline \multirow{2}{*}{ Item } & \multicolumn{3}{|c|}{ Factor loadings } & \multirow[b]{2}{*}{$h^{2}$} & \multirow[t]{2}{*}{$\begin{array}{l}\text { Item- } \\
\text { Total } r\end{array}$} \\
\hline & F1 & F2 & F3 & & \\
\hline $\begin{array}{l}\text { Due to their biological cycles (menstruation, birth, menopause etc.) } \\
\text { women cannot be productive in the work force. }\end{array}$ & .80 & .32 & .29 & .59 & 63 \\
\hline Women are not resilient to long and hard work conditions. & .76 & .36 & .50 & 62 & 63 \\
\hline Woman cannot tolerate pressures at work as much as men. & .63 & .38 & .51 & .57 & .64 \\
\hline Women should only work at jobs that suitable for women. & .41 & .88 & .40 & .49 & .57 \\
\hline are breadwinners they should be given priority in hiring. & .24 & .82 & .25 & .52 & .70 \\
\hline Domestic work is more suitable for women. & .39 & .61 & .41 & .67 & .66 \\
\hline $\begin{array}{l}\text { Presence of women at work places will decrease overall } \\
\text { productivity. }\end{array}$ & .38 & .33 & .94 & .66 & .60 \\
\hline $\begin{array}{l}\text { Women's use of their femininity for personal gain will cause unfair } \\
\text { conditions at work. }\end{array}$ & .34 & .32 & .73 & .74 & .69 \\
\hline Men should be preferred for administrative position. & .46 & .38 & .59 & .77 & .69 \\
\hline
\end{tabular}

The three-factor explained $63.9 \%$ of the total variance. The first factor consisted of three items, explained $41.7 \%$ of the total variance. This factor was called as "Gender Discrimination". The explained variance by the second factor was $12.1 \%$ and was called "Patriarchal Values". The third factor explained $10.1 \%$ of the total variance and labeled "Work Environment". The factor 
loadings of the items ranged between .59 and .94 . These findings provided evidence that the tri-factor scale had satisfactory construct validity.

The item-total test correlations took values between .57 and .70 (see Table 1). Item-total correlations of .30 or higher are evidence of the items' validity (Nunnally \& Bernstein, 1994). This also indicates that items in the scale measure the properties that they need to measure.

\section{CONCLUSION}

In summary, 32 draft items were created first. After qualitative evaluation of these items, it was decided to keep 24 items in the form. The EFA reduced the initial 24 items into 9 items formed three factors. Thus, Study 1 provided preliminary evidence for the structure and coherence of a measure of attitudes toward women's working.

\section{Study 2: Further Construct Validity, Reliability and Measurement Invariance across Gender}

In Study 1, the ATWWS was demonstrated to have distinguishable factor structure and sufficient convergent validity. To prove further evidence of its validity the factor structure extracted from previous study (in study 1) tested on a new sample. To confirm factor structure confirmatory factor analysis was performed. However, providing model fit does not guarantee that the scores obtained from the scale are comparable between the groups (Messick, 1995). Therefore, measurement invariance test was conducted across gender in Study 2.

\section{METHOD}

\subsection{Participants}

Participating in this study 2 were 600 undergraduate students. The convenience sample included $308(51.33 \%)$ females and 292 (48.67\%) males. Participants' age ranged between 19 and 26 years $\left(M_{a g e}=21.67, S D=1.43\right)$.

\subsection{Instruments}

In the first study a 9-item scale was yielded. This scale was named as the attitude toward women's working scale (ATWWS). The ATWWS was applied to participants in the study 2.

\subsection{Data Analysis}

Confirmatory factor analysis (CFA) was performed to investigate whether the factor structure obtained in the previous study fits to the data obtained from another sample. Confirmatory factor analysis is a psychometric assessment that permits comparing a priori factor structure based on multiple fit assessment procedures (Morin, Arens, \& Marsh, 2016). In the literature, it has been recommended that CFI, RMSEA, TLI and GFI should be preferred to evaluate model data-fit in CFA (Hu \& Bentler, 1999; Weston, Gore, Chan, \& Catalano, 2008). CFI, TLI and GFI values above .90 are acceptable, although values above .95 are more preferred (Kline, 2011). RMSEA values up to .06 (Brown \& Cudeck, 1992; Yuan, 2005) and SRMR values up to .08 (Brown, 2006) are reasonably good fit. The chi-square test for model fit is expected to be insignificant, however, a significant value may not necessarily mean that there is poor model fit. Because of the large sample size, it is often inflated, so $\chi^{2} / d f$ less than 3 (or even 5) considered acceptable for good model fit. In order to assess the reliability of ATWWS' subscales Cronbach's alpha coefficients were calculated.

\subsubsection{Measurement Invariance tests.}

Multiple-group confirmatory factor analysis (MGCFA) was performed to examine gender invariance. In this procedure, the equality of model parameters is tested using a nested hierarchy model comparison based on the chi-square tests (Brown, 2006; Byrne, 2004). A more restrictive 
hypothesis is proposed at each stage, thereby increasing the evidence for measurement invariance is provided. First, two CFAs were conducted for male and female participants separately. Next, procedure involved observing for significant changes in chi-square test values after constraining namely configural, metric, scalar, and strict invariance. If the chi-square difference across the models is not statistically significant then invariance is achieved (Dimitrov, 2010). This procedure, referred to as the forward approach because the analysis launches with the baseline model and goes towards to the more constrained model. In addition to chi-square difference test, a change of in $\mathrm{CFI}$ (e.g. $\triangle \mathrm{CFI}=\mathrm{CFI}_{\mathrm{M} 1}-\mathrm{CFI}_{\mathrm{M} 0}$ ) value is assessed for the nested models. $\Delta \mathrm{CFI}<-0.01$ would show a deficiency of invariance (Dimitrov, 2010). That is, a positive $\triangle \mathrm{CFI}$ indicates fit improvement; this result points out that invariance has been achieved (Dimitrov, 2010). Reporting $\Delta$ CFI, along with $\Delta \chi^{2}$, assessing a change in RMSEA is also proposed. $\triangle \mathrm{RMSEA} \geq 0.015$ would indicate lack of invariance (problematic values) (Chen, 2007). All tests were carried out using maximum likelihood estimation in LISREL.

\section{FINDINGS}

\subsection{Data Screening}

Prior to conducting the analysis, data were examined for missing values and outliers. Eleven missing values and eight outliers were dropped from the data set. The analyzes were continued with 581 (291 female and 290 male) data.

\subsection{Confirmatory Factor Analysis}

The nine items selected from the exploratory phase were used in CFA to verify the tri-factor structure of the ATWWS. The measurement model summarized in Table 2 was tested to verify the relationship between observable variables and latent constructs. The $\chi^{2}$-to- $d f$ ratio was in the acceptable range $\left(\chi_{(24)}^{2}=47.39, p=.003, \chi^{2} / d f=1.97\right)$, and all fit indices were highly satisfactory $(\mathrm{CFI}=.99, \mathrm{TLI}=.98, \mathrm{GFI}=.98 ; \mathrm{NFI}=.98, \mathrm{AGFI}=.95, \mathrm{SRMR}=.033, \mathrm{RMSEA}=.049)$ for a first-order CFA. Then, a second-order model was evaluated. The $\chi^{2}$-to- $d f$ ratio was fairly well $\left(\chi^{2}(24)=47.13, p=.003, \chi^{2} / d f=1.96\right)$, and a quite enough fit was obtained (CFI=.98, TLI=.97, $\mathrm{GFI}=.98 ; \mathrm{NFI}=.98$, AGFI=.95, $\mathrm{SRMR}=.028$, RMSEA=.048) for the second-order CFA. Findings demonstrated that the second-order model provided also a good fit to the data.

Table 2. The CFA measurement model for the tri-factor ATWWS

\begin{tabular}{|c|c|c|c|}
\hline Latent variables & Observed variables & Coefficients & $\begin{array}{c}\text { Error } \\
\text { Terms } \\
\end{array}$ \\
\hline \multirow{3}{*}{$\begin{array}{l}\text { Gender } \\
\text { Discrimination }\end{array}$} & $\begin{array}{l}\text { Due to their biological cycles (mensturation, pregnancy, } \\
\text { childbirth, menapous etc.) women cannot be productive in the } \\
\text { work force. }\end{array}$ & .62 & .62 \\
\hline & Women are not resilient to long and hard work conditions. & .61 & .63 \\
\hline & Woman cannot tolerate pressures at work as much as men. & .60 & .64 \\
\hline \multirow{3}{*}{$\begin{array}{l}\text { Patriarchal } \\
\text { Values }\end{array}$} & Women should only work at jobs that suitable for women. & .83 & .31 \\
\hline & $\begin{array}{l}\text { Since men are breadwinners they should be given priority in } \\
\text { hiring. }\end{array}$ & .69 & .52 \\
\hline & Domestic work is more suitable for women. & .62 & .62 \\
\hline \multirow{3}{*}{$\begin{array}{l}\text { Work } \\
\text { Environment }\end{array}$} & $\begin{array}{l}\text { Presence of women at work places will decrease overall } \\
\text { productivity. }\end{array}$ & .63 & .60 \\
\hline & $\begin{array}{l}\text { Women's use of their femininity for personal gain will cause } \\
\text { unfair conditions at work. }\end{array}$ & .78 & .39 \\
\hline & Men should be preferred for administrative position. & .71 & .50 \\
\hline
\end{tabular}




\subsection{Measurement Invariance across Gender}

At this stage firstly confirmatory factor analzes were conducted for male and female participants separately. Both the first-order and the second-order CFAs for ATWWS were showed one by one for females and males in Table 3. The first-order and the second-order threefactor solutions yielded superior fit indices for both samples, with the model fitting the females slightly better.

Table 3. Fit indices of the 9-item three-factor ATWWS across Gender

\begin{tabular}{lccccccccc}
\hline Group & CFA Model & $\chi^{2}$ & $d f$ & $p$ & $\chi^{2} / d f$ & CFI & TLI & GFI & RMSEA \\
\hline Females & $1^{\text {st }}$ order & 26.53 & 24 & .327 & 1.10 & .99 & .98 & .98 & .019 \\
& $2^{\text {nd }}$ order & 22.47 & 24 & .551 & .936 & 1.0 & 1.0 & .98 & .000 \\
Males & $1^{\text {st }}$ order & 37.80 & 24 & .036 & 1.57 & .98 & .98 & .97 & .044 \\
& $2^{\text {nd }}$ order & 39.04 & 24 & .027 & 1.63 & .98 & .97 & .97 & .047 \\
\hline
\end{tabular}

Multiple-group analyzes for each group were performed to establish baseline model. Subsequent analyses were conducted by adding each more constraint to the next model. As shown in Table 4, configural invariance had acceptable fit to the data. This indicated that the correlated three-factor structure held across males and females. Since the configural invariance was achieved, then the factor loadings were constrained. Metric invariance model appeared fit to the data well, and also better compared to the configural model $\left(\Delta \chi^{2}=16.61, \Delta d f=6\right.$, $p=.011>.01)$. Chi-square difference value was insignificant; $\Delta$ CFI (.00) more than -.01 and $\triangle$ RMSEA (.002) less than .015 indicated that model had metric invariance across gender. Scalar model fitted adequately to the data. When two models compered it appeared that the scalar model indicated worse fit than the metric model $\left(\Delta \chi^{2}=70.69, \Delta d f=14, p=.000\right)$. Besides, $\Delta \mathrm{CFI}=$ -.04 less than -.01 pointed to evidence for the lack of scalar invariance. Likewise, even though the strict invariance model yielded adequate fit to the data, but could not achieve better fit according to the scalar model $\left(\Delta \chi^{2}=66.71, \Delta d f=9, p=.000\right)$. Compared to scalar model, strict model resulted in a change in CFI (-.02) less than -.01, thus evidence for strict invariance was not attained.

Table 4. Tests of Measurement Invariance

\begin{tabular}{lccccccccccc}
\hline Model & $\chi^{2}$ & $d f$ & $p$ & $\chi^{2} / d f$ & CFI & TLI & RMSEA & $\Delta \chi^{2}$ & $\Delta d f$ & $p$ & $\Delta$ CFI \\
\hline Configural & 80.57 & 48 & .002 & 1.67 & .98 & .97 & .042 & - & - & - & - \\
Metric & 97.18 & 54 & .000 & 1.79 & .98 & .97 & .046 & 16.61 & 6 & .011 & 0.0 \\
Scalar & 167.87 & 60 & .000 & 2.79 & .94 & .93 & .069 & 70.69 & 14 & .000 & -.04 \\
Strict & 234.58 & 69 & .000 & 3.39 & .92 & .91 & .080 & 66.71 & 9 & .000 & -.02 \\
\hline
\end{tabular}

\subsection{Convergent Validity}

In order to evaluate convergent validity of the ATWWS-9, Pearson correlations between ATWWS-9 total score and its subscales were computed. The correlations between subscales were presented in Table 5. Pearson correlations between the factors were significant and positive. Each subscale had moderate correlations with others. Moderate correlations indicate that each subscale is related to the others, but still sufficiently different. The Pearson correlations between each factor and the total scale score were found positive, strong, and significant (see Table 5). 
Table 5. Correlations between ATWWS subscales

\begin{tabular}{lcccc}
\hline ATWWS & F1 & F2 & F3 & Total \\
\hline F1 & - & $.580^{* *}$ & $.481^{* *}$ & $.827^{* *}$ \\
F2 & & - & $.467^{* *}$ & $.812^{* *}$ \\
F3 & & & - & $.814^{* *}$ \\
\hline
\end{tabular}

**Correlation is significant at the 0.01 level.

\subsection{Internal Consistency}

The Cronbach's alpha values found as .70, .72 and .74, for Gender Discrimination, Patriarchal Values and Work Environment respectively. The overall Cronbach's alpha for the scale was calculated as .81 . Seventy percent or higher internal consistency coefficient is considered to be sufficient for the reliability.

\section{GENERAL DISCUSSION}

The main aim of this current multi-study investigation was to develop a scale measuring attitudes of young adults toward women's working. The attitude toward women's working scale was developed by the researcher. It was a tri-factor scale consisting nine Likert-type items. Participiants rated each item on a scale from 1 (strongly disagree) to 5 (strongly disagree). In Study 1 the scale was administrated to 364 young adults. The initial construct validity of the scale was determined by EFA. All items displayed moderate to high loadings on their respective factors, in a sense that all items contribute similarly to the latent variables. The 9-item tri-factor scale accounted for $64.9 \%$ of the total variance.

In Study 2, both the first and the second-order CFA's were performed to investigate whether the data support the proposed model of the scale on a different sample. Findings pointed out strong support for both the first-order and the second-order model consistent with the exploratory factor analysis in the whole group and in the gender groups. These results shored up the theoretical conceptualization of attitude toward women working as a sole construct comprising of the three related but independent dimensions. In short, the fit index values of the structural model confirmed the further construct validity of the scale. The Cronbach's alphas values were .70 for Gender Discrimination, .72 for Patriarchal Values and .74 for Work Environment. These reliabilities demonstrated sufficient internal consistency considering the few number of items included in each sub-scale. In addition, Pearson correlations between the factors were calculated. The three subscales demonstrated moderate, positive and significant correlations among each other. This means that although each of the three factors seems to share a common essence, each represents a separate dimension. Thus, three subscales demonstrated modest evidence of convergent validity.

Then, gender invariance of the latent construct was evaluated with MGCFA. The MGCFA findings indicated that configural and metric invariance is completely achieved for the threefactor structure of ATWWS across gender. Configural invariance means that the scale had the same number of factors in both females and males. Obtaining the configural invariance also shows that the items under each factor are the same across the groups. If the factor structures are the same between both groups, this showes that male and female participiants use a similar conceptual domain (Riordan \& Vandenberg, 1994). Providing metric invariance implies that the equality of factor loadings is accepted between gender. Establishing the invariance of factor loadings means that participiants calibrate the intervals used on the measurement scale in similar ways (Riordan \& Vandenberg, 1994). In other words, the intercourses between the latent factor and external variables can be compared among gender because a one-unit change in females would be equal to one-unit change in the males (Dimitrov, 2010).

Although scalar invariance was not met, the constraints resulted in a slightly decrease but still 
acceptable model fit. Failure to support scalar invariance means item intercepts may be different. Since women are traditionally thought to have different attitudes from men (Dex, 1988), it is not unexpected that women and men have different reference points in regarding the construct examined. Chen (2008) stated that intercept lack of invariance could take place due to social norms. Where dominant social and cultural norms exist (such as Turkey), gender differences in attitudes towards women's participation in social and economic life are expected (Koca, Arslan, \& Aşç1, 2011). On the other hand, although having the same factor mean, the fact that a particular group tends to react more strongly to an item can lead to scalar noninvariance (Chen, 2008).

In literature, scalar invariance was discussed less frequently because location parameters (intercepts) are often treated as being arbitrary and sample specific (Vandenberg \& Lance, 2000). Lubke and Muthen (2004, p.516) stated "Threshold differences between groups indicate that groups use a given Likert scale in a group-specific way and are a violation of MI (Millsap \& Tein, 2003), whereas threshold differences between the observed indicators of a factor do not violate MI" and they added "The MI model may be rejected because threshold differences between observed indicators can lead to a distorted factor structure or because indexes of goodness of fit based on the assumption of normally distributed data do not work properly" ( $p$. 516). They also conclude such a case "would lead a researcher to believe that MI is violated when in fact it is not" (Lubke \& Muthen, 2004, p.516). In sum, because of scalar invariance could not be achieved, it would be concluded that differences in the intercepts across the gender could exist. Since the main purpose of this study was not determined to make group comparisons and the proposed modifications on items did not improve the model fit, the investigation was not continued. However, if future research is planning to be compared in gender groups, scalar invariance should be examined. According to findings, strict invariance was not met. The lack of strict invariance however does not indicate that the scale is inconvenient for utilization among the groups, as the critical prerequisite for cross-group comparisons is metric and scalar invariance (Cheung \& Rensvod, 2002).

\section{GENERAL CONCLUSION}

In sum, a brief 9-item, tri-factor scale for the assessment of attitudes toward women's working is developed. This scale reflects the multifaceted nature of the latent construct; with a factor structure revealed through EFA and verified conducting CFA. According to results obtained in the second level CFA, it is possible to state a total score can be obtained regarding the attitudes towards women's working. However, depending on the purpose of the prospective studies, the scores obtained from the subscales can also be used separately. The responses collected by a five-point Likert-type scale ranging from strongly disagree (1) to strongly agree (5). Therefore, the high score obtained from the sub-scales and overall of the scale shows that negative attitudes towards women's working are high. Based on the findings, it can be stated that the ATWWS has satisfactory psychometric features. This study also supports the use of the ATWWS in its current configural and metric invariance for females and males. In other words, the scores of males and females obtained from the scale can be compared in terms of factor form and factor loadings.

Since the participants of these studies were recruited with convenience sampling, this procedure may limit the generalizability of the findings. It is recommended to use probability based sampling methods (such as simple random or stratified random sampling) for future research. Although successive studies were conducted in two different samples in this current study, instrument validation is an ongoing process and future psychometric studies are needed to further investigate the psychometric properties of the ATWWS and improve its generalizability. Furthermore, the results are limited to young Turkish adults due to the nature of the study from which the data were obtained. Studies for individuals in different developmental stages and in 
larger samples may be able to provide further robust validation. Even though the present evidence revealed that the ATWWS is a psychometrically strong instrument, further investigation is necessary to warrant its use over time.

Measurement invariance was conducted only for gender. Future research on the invariance of the construct across age, parent education level and/or socio-economic status would be concerning. Because scalar invariance is not provided, it is recommended that researchers who want to compare scale scores on gender groups should be cautious in making interpretations.

In spite of the limitations, the current study has some implications. First, the ATWWS is a short and easy-to-administer self-report measure. Second, multidimensional nature of the scale allows researchers to make more clear interpretations of the test scores as well as the construct. Finally, assessment instruments having strong psychometric properties are critical for advancing social research. Thus, this study helps refine the understanding of conceptualization of attitudes toward women's working in the labor market.

This study also has educational implications. Determining the attitudes of young generations toward women's working is crucial in shedding light for the efforts geared toward facilitating positive attitudes. Determining the level of attitudes toward women's working will contribute to the awareness on this issue for all actors in economic and social life as well as for educators and policy makers. This kind of awareness can help to increase initiatives to improve social justice. Educators also play vital roles in developing and transforming attitudes. Therefore, developing attitudes toward women's working through education will make society more accessible to a stronger and fair labor distribution.

\section{Declaration of Conflicting Interests and Ethics}

The authors declare no conflict of interest. This research study complies with research publishing ethics. The scientific and legal responsibility for manuscripts published in IJATE belongs to the author(s).

\section{ORCID}

Devrim Erdem (D) https://orcid.org/0000-0003-1810-2454

\section{REFERENCES}

Agapiou, A. (2002). Perceptions of gender roles and attitudes toward work among male and female operatives in the Scottish construction industry. Construction Management \& Economics, 20(8), 697-705. DOI: 10.1080/0144619021000024989

Ajzen, I. (1989). Attitude Structure and Behavior, In A. R. Pratkanis, S. J. Breckler, and A. G. Greenwald (Eds.), Attitude Structure and Function, Lawrence Erlbaum Associates, Hillsdale, NJ, 241-274.

Akın, F. (2002). Kadınların işgücüne katılımı ve işteki durum tercihinin Nested Logit Model ile Analizi [Women's labor force participation and job status preference analysis with Nested Logit Model]. METU/ERC International Conference in Economics VI, Ankara, Turkey, September 2002.

Aktaş, G. (2013). Feminist söylemler bağlamında kadın kimliği: Erkek egemen bir toplumda kadın olmak [Female identity in the context of feminist discourses: Being a woman in a male-dominated society]. Journal of Faculty of Letters, 30(1), 53-72.

Allport, G.W. (1935). Attitudes. In C. Murchison (Ed) Handbook of Social Psychology, Worcester, Mass: Clark University Press.

Alwin, D.F., Braun, M., \& Scott, J. (1992). The separation of work and the family: Attitudes towards women's labour-force participation in Germany, Great Britain, and the United States. European Sociological Review, 8(1), 13-37. https://www.jstor.org/stable/522315 
Bianchi, S.M., Milkie, M.A., Sayer, L.C., \& Robinson, J.P. (2000). Is Anyone Doing the Homework? Trends in the Gender Division of Household Labor. Social Forces, 79(1), 191-228.

Bingöl, O. (2014). Toplumsal cinsiyet olgusu ve Türkiye'de kadınlık [The concept of gender and femininity in Turkey]. KMU Journal of Social and Economic Research, 16(1), 108114.

Blackton, R.R. (1986). A study of the correlation between the degree of acculturation and scholastic achievement and English gain of ESL students, grades 2-5, Beach School, Portland, Oregon. Dissertations and Theses. Paper 3560.

Bora, A. (2011). Kadınların sınıfı ücretli ev emeği ve kadın öznelliğinin inşası [Women's class paid home labor and the construction of female subjectivity]. İstanbul: İletişim Publications.

Bölükoğlu, A. (2018). Yedek işgücü olarak kadın emeği: Türkiye Örneği:1988-2013 [Women's labor as a reserve labor force: The Case of Turkey]. Journal of Economics, Policy \& Finance Research, 3(1), 50-67.

Brewe, E., Kramer, L., \& O’Brien, G. (2009). Modeling instruction: Positive attitudinal shifts in introductory physics measured with CLASS. Physical Review Special Topics-Physics Education Research, 5(1), 013102.

Britton, D.M. (2000). The epistemology of the gendered organization. Gender and Society, $14(3), 418-434$.

Brown, T. (2006). Confirmatory factor analysis for applied research. New York, NY: Guilford Press.

Browne, M., \& Cudeck, R. (1992). Alternative ways of assessing model fit. Sociological Methods and Research, 21(2), 230-258.

Byrne, B.M. (2004). Testing for multigroup invariance using AMOS graphics: A road less traveled. Structural Equation Modeling, 11(2), 272-300. DOI: 10.1207/ s15328007sem1 1028

Chen, F.F. (2007). Sensitivity of goodness of fit indexes to lack of measurement invariance. Structural Equation Modeling: A Multidisciplinary Journal, 14(3), 464-504.

Chen, F.F. (2008). What happens if we compare chopsticks with forks? The impact of making inappropriate comparisons in cross-cultural research. Journal of Personality and Social Psychology, 95, 1005-1018.

Cheung, G.W., \& Rensvold, R. B. (2002). Evaluating goodness-of-fit indexes for testing measurement invariance. Structural Equation Modeling: A Multidisciplinary Journal, 9(2), 233-255. DOI: 10.1207/S15328007SEM0902 5

Coltrane, S. (2000). Research on household labor: Modeling and measuring the social embeddedness of routine family work. Journal of Marriage and the Family, 62, 12081233.

Corrigall, E.A., \& Konrad, A.M. (2007). Gender role attitudes and careers: A longitudinal study. Sex Roles, 56(11-12), 847-855. https://doi.org/10.1007/s11199-007-9242-0

Costello, A., \& Osborne, J. (2005). Best practices in exploratory factor analysis: Four recommendations for getting the most from your analysis. Practical Assessment, Research and Evaluation, 10(7), 1-9.

Çiçek, B., \& Çopur, Z. (2018). Bireylerin kadınların çalışmasına ve toplumsal cinsiyet rollerine ilişkin tutumları [Attitudes of individuals towards women's work and gender roles]. International Journal of Eurasian Education and Culture, 4, 1-21.

Dayioglu, M., \& Kirdar, M.G. (2010). Determinants of and trends in labor force participation of women in Turkey (English). Welfare and social policy analytical work program; working paper no. 5. Washington DC: World Bank. http://documents.worldbank.org/cur 
ated/en/466591468316462301/Determinants-of-and-trends-inlabor-force-participationof-women-in-Turkey.

Dex, S. (1988). Women's attitudes towards work. Springer.

Dimitrov, D.M. (2010). Testing for Factorial Invariance in the Context of Construct Validation. Measurement and Evaluation in Counseling and Development, 43(2) 121-149.

Dökmen, Z.Y. (2004). Toplumsal Cinsiyet: Sosyal Psikolojik Açılkamalar [Gender: Social Psychological Explanations]. İstanbul: Sistem Publishing.

Erkuş, A. (2012). Varolan ölçek geliştirme yöntemleri ve ölçme kuramları psikolojik ölçek geliştirmede ne kadar işlevsel: Yeni bir öneri [Existing scale development methods and measurement theories how functional are psychological scale development: A new proposal]. Journal of Measurement and Evaluation in Education and Psychology, 3(2), 279-290.

Ersoy, E. (2009). Cinsiyet kültürü içerisinde kadın ve erkek kimliği: Malatya Örneği [Male and female identity in gender culture: Malatya Case]. Firat University Journal of Social Sciences, 19(2), 209-230.

Fabrigar, L.R., MacDonald, T. K., \& Wegener, D. T. (2005). The Structure of attitudes from: The Handbook of Attitudes Routledge. Accessed on: 21 May 2019. https://www.routledgehandbooks.com/doi/10.4324/9781410612823.ch3

Fabrigar, L. R. \& Wegener, D. T. (2010). Attitude structure. Em R. F. Baumeister \& E. J. Finkel (Orgs.), Advanced social psychology: The state of the science (pp. 177-216). New York: Oxford University Press.

Ferrao, V. (2010). Paid work. Women in Canada: A Gender-Based Statistical Report. Sixth edition. Statistics Canada. Catalogue 89-503X.

Forsythe, N., Korzeniewicz, R.P., \& Durrant, V. (2000). Gender inequalities and economic growth: A longitudinal evaluation. Economic Development and Cultural Change, 48(3), 573-617. https://www.jstor.org/stable/10.1086/452611.

Fredricks, J.A., Blumenfeld, P.C, \& Paris, A.H. (2004). School engagement: Potential of the concept, state of the evidence. Review of Educational Research, 74, 59-109.

GGGR (2018). https://www.weforum.org

Glasman, L.R., \& Albarracín, D. (2006). Forming attitudes that predict future behavior: A metaanalysis of the attitude-behavior relation. Psychological Bulletin, 132(5), 778-822.

Gubernskaya, Z. (2010). Changing attitudes toward marriage and children in six countries. Sociological Perspectives, 53, 179-200.

Gürler, Ö., \& Üçdoruk, Ş. (2007). Türkiye'de cinsiyete göre gelir farklılığının ayrıştırma yöntemiyle uygulanması [Applying the decomposition method of income differences by gender in Turkey]. Journal of Yasar University, 2(6), 571-589.

Heilman, M.E. (2001). Description and prescription: How gender stereotypes prevent women's ascent up the organizational ladder. Journal of Social Issues, 57(4), 657-674.

Hersch, J., \& Stratton, L. (2002). Housework and Wages. The Journal of Human Resources, 37(1), 217-229. DOI:10.2307/3069609

Himmelweit, S. (2002). Making visible the hidden economy: The case for gender-impact analysis of economic policy. Feminist Economics, 8(1), 49-70. DOI: $10.1080 / 13545700110104864$

Hinner, M.B. (2019). The cultural perspective of mergers \& acquisitions: An exploratory study. In J. Stumpf-Wollersheim \& A. Horsch (Eds.), Forum mergers \& acquisitions. Springer Gabler, Wiesbaden.Hu, L., \& Bentler, P.M. (1999). Cutoff criteria for fit indexes in covariance structure analysis: Conventional criteria versus new alternatives. Structural Equation Modeling, 6(1), 1-55. https://doi.org/10.1080/10705519909540118. 
Kakıcı, H., Emeç, H., \& Üçdoğruk, Ş. (2007). Türkiye'de çalışan kadınların çocuk bakım tercihleri [Child care preferences of working women in Turkey]. Istanbul University Faculty of Economics Journal of Econometrics and Statistics, 5, 20-40.

Kaufman, G., \& Uhlenberg, P. (2000). The Influence of Parenthood on the Work Effort of Married Men and Women. Social Forces, 78(3), 931-947. DOI:10.2307/3005936

Kılıç, D., \& Öztürk, S. (2014). Türkiye'de kadınların işgücüne katılımı önündeki engeller ve çözüm yolları: Bir ampirik uygulama [Barriers to women's labor force participation and solutions in Turkey: An empirical application]. Journal of Public Administration,47(1), 107-130.

Kıral, G., \& Karlılar, S. (2017). Türkiye'de kadın işgücüne katılımını etkileyen faktörler: Adana ili üzerine bir uygulama [Factors affecting the labor force participation of women in Turkey: Adana province on an application]. Journal of Çukurova University Institute of Social Sciences, 26(3), 272-286.

Kırkpınar, L. (2001). Türkiye'de toplumsal değişme ve kadın [Social change and women in Turkey]. Ankara: Ministry of Culture Publications.

Kızılırmak, A.B. (2005). Labor market participation decisions of married women: Evidence from Turkey. Oxford University Press: Oxford.

Kline, R.B. (2011). Principles and practice of structural equation modeling. New York: The Guilford Press.

Koca, C., Arslan, B., \& Aşçı, F.H. (2011). Attitudes towards women's work roles and women managers in a sports organization: The case of Turkey. Gender, Work \& Organization, 18(6), 592-612. DOI:10.1111/j.1468-0432.2009.00490.x

Koray, M. (1992). Çalışma yaşamında kadın gerçekleri [Woman facts in working life]. Journal of Public Administration, 25(1),93-122

Köseoğlu, S. (2017). Erkek üniversite öğrencilerinin kadınların çalışmasına yönelik tutum ölçeği [The attitude scale of male university students towards the work of women]. TBB Journal, 30, 303-312.

Kuzgun, Y., \& Sevim S.A. (2004). Kadınların çalışmasına karşı tutum ve dini yönelim arasındaki ilişki [The relationship between attitude towards women's work and religious orientation]. Ankara University Journal of Faculty of Educational Sciences, 37(1), 14-27.

Lips, H.M. (2001). Sex and Gender: An Introduction. California: Mayfield Publishing Company.

Lubke, G.H., \& Muthén, B.O. (2004) Applying multigroup confirmatory factor models for continuous outcomes to likert scale data complicates meaningful group comparisons. Structural Equation Modeling: A Multidisciplinary Journal, 11(4), 514-534. DOI: 10.1207/s15328007sem1104 2

Maio, G.R., Haddock, G., \& Verplanken, B. (2018). The psychology of attitudes and attitude change. Sage Publications Limited.

Messick, S. (1995). Validity of psychological assessment: Validation of inferences from persons' responses and performances as scientific inquiry into score meaning. American Psychologist, 50, 741-749.

MLSSF (2014). Analysis of the female labor force profiles and statistics in Turkey. http://kadininstatusu.aile.gov.tr/

Morin, A.J.S., Arens A.K., \& Marsh, H.W. (2016). A bifactor exploratory structural equation modeling framework for the identification of distinct sources of construct- relevant psychometric multidimensionality. Structural Equation Modeling: A Multidisciplinary Journal, 23,116-39.

Negiz, N., \& Yemen, A. (2011). Kamu örgütlerinde kadın yöneticiler: Yönetici ve çalışan açısından yönetimde kadın sorunsalı [Women executives in public organizations: 
Women's problem in management in terms of managers and employees]. SDU Faculty of Arts and Sciences Journal of Social Sciences, 24, 195-214.

Noor, A.M., \& Saad, R.A.J. (2016). The mediating effect of trust on the relationship between attitude and perceived service quality towards compliance behavior of zakah. International Journal of Economics and Financial Issues, 6(7S), 27-31. available online at: www.econjournals.com

Nunnally, J.C., \& Bernstein, I. (1994). Psychometric theory. New York: McGraw-Hill.

OECD (2016). Labor force statistics: Labor force participation rate. www.oecd/data

Özar, Ş. (2005). GAP Bölgesi'nde kadın girişimciliği [Women entrepreneurship in the GAP Region]. Ankara, GAP-GIDEM Publications, January.

Özçatal, E.Ö. (2011). Ataerkillik, toplumsal cinsiyet ve kadının çalışma yaşamına katılımı [Patriarchy, gender and women's participation in working life]. Çankırı Karatekin University Journal of Economics and Administrative Sciences, 1(1), 21-39.

Özkaplan, N. (2013). Kadın akademisyenler: Cam tavanlar hâlâ çok kalın! [Female academics: Glass ceilings are still too thick!]. Journal of Women's Studies, 12(1), 1-23.

Palaz, S. (2015). The reasons for women's labor force non-participation: Empirical evidence from Bandırma. Journal of Management and Economics Research, 13(3), 435-449.

Perkins, K. K., Adams, W.K., Pollock, S.J., Finkelstein, N.D., \& Wieman, C.E. (2005). Correlating student beliefs with student learning using the Colorado Learning Attitudes about Science Survey. In AIP Conference Proceedings, 790(1), 61-64.

Powell, A. (2019). Women and the Economy. Briefing paper. Number CBP06838.

Rentz, J.O., Shepherd, C. D., Tashchian, A., Dabholkar, P.A., \& Ladd, R.T. (2002). A measure of selling skill: Scale development and validation. Journal of Personal Selling \& Sales Management, 22(1), 13-21. https://doi.org/10.1080/08853134.2002.10754289

Riordan, C. M., \& Vandenberg, R. J. (1994). A central question in cross-cultural research: Do employees of different cultures interpret work-related measures in an equivalent manner. Journal of Management, 20, 643-671.

Scott, J. \& Clery, E. (2013). Gender roles: An incomplete revolution? In Park, A., Bryson, C., Clery, E., Curtice, J. and Phillips, M. (Eds.) (2013), British Social Attitudes: the 30th Report, London: NatCen Social Research. Available online at: www.bsa-30.natcen.ac.uk

Şengül, S., \& Kıral, G. (2006). Türkiye'de kadının işgücü pazarına katılım ve doğurganlık kararları [Participation of women in the labor market and fertility decisions in Turkey]. Atatürk University Journal of Economics and Administrative Sciences, 20(1), 89-99.

Tabachnick, B.G., \& Fidell, L.S. (2001). Using multivariate statistics (4th ed.). Needham Heights, MA: Allyn \& Bacon.

Tan, M. (2000). Ĕ̆itimde kadın-erkek eşitliği ve Türkiye gerçeği. Kadın-Erkek Eşitliğine Doğru Yürüyüs-Eğitim, Çalışma Yaşamı ve Siyaset içinde. [Gender equality and the reality of Turkey in education. Walking towards equality between men and women-in education, working life and politics]. Ankara: TÜSİAD Publications.

Tansel, A. (2002). Economic development and female labor force participation in Turkey: Time series evidence and cross-province estimates. Economic Research Center Working Paper in Economics, 1(5), 1-37.

TUIK (2016). Labor force statistics: 2007-2016. http://www.tuik.gov.tr

TUIK (1990). http://www.tuik.gov.tr

TUIK (2000). http://www.tuik.gov.tr

UN (2012). United Nations. The Millennium Development Goals Report 2012. Retrieved August 17, 2019, https://www.un.org/millenniumgoals/pdf/MDG\%20Report\%202012.p $\underline{\mathrm{df}}$

U.S. Bureau of Labor Statistics (2019). Retrieved September 3, 2019, from https://statusofwomendata.org/explore-the-data/employment-and-earnings/ 
Vandenberg, R.J., \& Lance, C.E. (2000). A review and synthesis of the measurement invariance literature: suggestions, practices, and recommendations for organizational research. Organizational Research Methods, 3(1), 4-70.

Weston, R., Gore Jr, P. A., Chan, F., \& Catalano, D. (2008). An introduction to using structural equation models in rehabilitation psychology. Rehabilitation Psychology, 53(3), 340-356. DOI: $10.1037 / \mathrm{a} 0013039$

Worthington, R., \& Whittaker, T. (2006). Scale development research: A content analysis and recommendations for best practices. Counseling Psychologist, 34, 806-838.

Yamak, R., Abdioğlu, Z., \& Mert, N. (2012). Türkiye'de işgücüne katılımı belirleyen faktörler: Mikro ekonomik analiz [Determinants of labor force participation in Turkey: Microeconomic analysis]. Anadolu University Journal of Social Sciences, 12(2), 41-58.

Yıldırım, K., \& Doğrul, G. (2008). Çalışmak ya da Çalışmamak: Türkiye'de Kentsel Alanlarda Yaşayan Kadınların İşgücüne Katılmama Kararlarının Olası Belirleyicileri [Work or not work: Possible Determinants of Women Living in Urban Areas in Turkey's decision not to participate in the labor force]. Anadolu University Journal of Social Sciences, 8(1), 239-262.

Yinger, R.J. (1980). Can we really teach them to think? In R. E. Young (Ed.), Fostering critical thinking. San Francisco: Jossey-Bass Inc

Yuan, K. H. (2005). Fit statistics versus test statistics. Multivariate Behavioral Research, 40, 115-148. 


\section{APPENDIX: Turkish form of the scale}

Table A1. Kadınların Çalışmasına yönelik Tutum Ölçeği

\begin{tabular}{|c|c|c|}
\hline Boyut & Madde no & Türkçe Form \\
\hline \multirow{3}{*}{$\begin{array}{l}\text { Cisiyete dayalı } \\
\text { Ayrımcilık }\end{array}$} & M1 & $\begin{array}{l}\text { Kadınlar biyolojik döngüleri (regl, hamilelik, doğum, menopoz } \\
\text { vb.) dolayısıyla iş yerinde verimli olamaz. }\end{array}$ \\
\hline & M2 & $\begin{array}{l}\text { Kadınlar uzun ve ağır çalışma koşullarına erkekler kadar } \\
\text { dayanıklı değildir. }\end{array}$ \\
\hline & M3 & $\begin{array}{l}\text { Kadınlar psikolojik olarak iş baskısını erkekler kadar tolere } \\
\text { edemez. }\end{array}$ \\
\hline \multirow{3}{*}{ Ataerkil Değerler } & M4 & Kadınlar sadece kadınlara has işlerde çalışmalıdır. \\
\hline & M5 & $\begin{array}{l}\text { İşe alımlarda erkeklere öncelik verilmelidir çünkü erkek, ailenin } \\
\text { temel geçiminden sorumludur. }\end{array}$ \\
\hline & M6 & Kadınların çalışma ortamı evi olmalıdır. \\
\hline \multirow{3}{*}{ İş Ortamı } & M7 & İş yerinde kadınların olması verimi düşürür. \\
\hline & M8 & $\begin{array}{l}\text { Kadınların iş yerinde dişiliklerini kullanması haksız rekabete } \\
\text { yol açar }\end{array}$ \\
\hline & M9 & Yönetici pozisyonlara erkekler tercih edilmelidir. \\
\hline
\end{tabular}

